\title{
Стратегия «Открытие на север» и экономического и торгового сотрудничества Внутренней Монголии с Россией и Монголией
}

Л.ТҮмэнцээฺэг ( Научно-исследовательский институт по вопросу о соседних странах Института монголоведения университета Внутренней Монголии )

\section{1. Фон стратегии «Открытие на север»}

Китайская стратегия «Открытие на север» начинается с 90-х гг, она является важным компонентом реформы и открытости Китая. Внутренняя Монголия, которая узкая, за пределами и прилегающем к России, Монголии, протяженность границы 4221 км в пределах и прилегающей к провинциям Ганьсу, Шэньси и др. (всего 8) . Уникальное географическое положение определяет Внутреннюю Монголию в структуре Китая и открывает ее решительную позицию. В сопровождении открытия реформ Китая и открытия реализации на север, так что долгосрочный в отдаленных и отсталых северных границ, из которого Советского Союза конфронтации из тени, открыли для внешнего мира, великий исторический шанс развития экономики.

Китай осуществляет стратегию «открытия на север» во-первых в целях содействия экономическому развитию этнических районов, уменьшения диспропорций регионального развития в Китае. Во-вторых, в целях реализации добрососедства, безопасности и процветания соседей, растет международная стратегия мирного существования. Монголия, Сибирь и Дальний Восток были менее развитыми районами Россия, их экономическое развитие является очень сильным близко, спрос на рынке Китая. Кроме того в последние годы, многие компании в восточных провинциях, а также Гонконг и Макао имеют также базу во внутренней Монголии и России, Монголия для осуществления экономического и торгового сотрудничества. Это стратегия «Открытие на север» предлагает более широкое рыночное пространство и условия. В то же время Внутренняя Монголия достигает быстрого экономического развития в последние годы, существует настоятельная необходимость использовать иностранные ресурсы и открытия международного рынка, «выйти» - сильное желание предприятия. Промышленная структура России и Монголии также имеет очень сильные взаимодополнения.

\section{2. Эффективность торгово-экономического сотрудничества России и Монголии}

С момента начала реформы и открытости в Китае, Внутренняя Монголия «открытие на север» как важная точка опоры в развитии стратегии, торговое сотрудничество России 
и Монголии быстро развивается. К 2011 году, Внутренняя Монголия и Россия, Монголии в объём импорта и экспорта около 2,893 млрд. долл. США 2.845 млрд. долл. США увеличившись на 20,5\%, 68,3\%, два вместе составляли на 2011 год 48,1\% всего импорта и экспорта объема во внутренней Монголии.

В Внутренней Монголии 19 портов, 17 из них распространяется в уезде и городе, и построить стереоскопический, всестороннего открыт к северу от системы портов. Взять Маньчжурию для примера, город Маньчжурии в 1992 году был утвержден Государственным советом по делам Маньчжурии вдоль открытого города, и в то время Маньчжурия порт объемом всего 2.94 мил. тоннов. Государственных ведомств на «десятых пятилетний» и «Одиннадцатый пятилетний» план, всего инвестированного капитала более чем на 50 миллиардов, реализация Маньчжурии канала порта, осмотр, порта и железных дорог, аэропортов и других объектов инфраструктуры пассажирского порта и в больших размерах увеличивать способстность и эффективность растоможки. Особенно стоит отметить, в 2010 г. город Маньчжурия был утверждён Госсоветом статус «экспериментальная зона по приоритетному развитию и открытости», Внутренняя Монголия для реализации стратегии «открытие на север» с новыми шансами. В последние годы в городе Маньчжурия захват государства и автономной области для реализации на севере открыты стратегические возможности для укрепления связей с соседними областями России, Монголии, местного самоуправления, усилия по улучшению порта таможенного оформления и возможность повышения пространства вокруг строительства оформления порт таможенных, железнодорожных расширение и продолжение строительства и пересечения дорог. В 2011-ом объём перевозимых товаров достиг 26.596 млн тонн, более 60\% от объема торговли между Китаем и Россией проходит через пункт пропуска Маньчжурия, который все время занимает ведущую позицию среди сухопутных пунктов пропуска в Китае.Торгово-экономического сотрудничества остальных портов во Внутренней Монголии к России и Монголии тоже получают быстрое развитие. За последние годы, Россия и Монголия стали торговыми партнерами Внутренней Монголии на первом и втором месте, также являются основным и странами зарубежных контрактов и экспортом трудовой услуги.

\section{3. Проблемы, существующие при реализации стратегии «открытие на север»}

С момента начала стратегии «Открытие на север» добились больших успехов. Но в настоящее время все еще существуют несколько проблемов.

Во-первых, уровень стратегии «Выйти» необходимо повысить.В 2011 году Китай импортировал из Монголии, России, 20.4 млн. тонн рядового угля, руды и рудных 
продуктов 10.55 млн. тонн, количество которых увеличилось на 21.57\% и 134\% соответственно. Но китайских компаний, $\square$ занимающихся зарубежным развитием ресурсов мало, в деле импорта закупки товаров были главными и другие традиционные торговли. Проекты для получения права на добычу были малые проекты, покупать больше, разработок мало, а также меньше местных обработок. Поддаться влиянию колебаний рынка и торговой политики.

Во-вторых с точки зрения нынешней ситуации инвестиции Внутренней Монголии автономного региона в России, в Монголии гораздо более размыты. На протяжении “Одиннадцатой пятилеткой” 66 новых предприятий, Китай заключил контракт иностранных инвестиций в сумме около \$ 5.18 млн., единого соглашения инвестиций около 7.8 млн. долларов США. В 2011 г новые инвестиции в предприятиях и организациях, китайские индивидуальные согласованные инвестиции менее чем 35 млн. долларов США. В дополнение к крупным проектам, в настоящее время инвестиции являются также малыми и средними предприятиями, частными предприятиями. Мало инвестиций крупных предприятий. Из-за того существует слабая способность к защите от колебаний емкости рынка и легче возникнуют незаконные действия конкуренций.

B-третьих, до сих пор не решена проблема оптимизации структуры импорта и экспорта. В 2011 году ВВП достигли 1424.6 билл. Во Внутренней Монголии, но объём торговли по экспорту и импорту является только 11.94 билл. долларов, не совпадает серьёзно. Из-за нерациональной структуры экспорта и импорта стоимостной объём экспорта и импорта очень несбалансирован: 2011 г Внутренняя Монголия из России, Монголии импортирует около 2.68 билл. долларов США, 1.93 билл. долларов США. Но в Россию Монголию экспортирует около 2130 миллионов долларов США и 9100 миллионов долларов США.

В четвёртых с точки зрения открытой среды слабые инфраструктуры частной портов Внутренней Монголии, Монголии и России уже не смогут полностью удовлетворить потребности торговли. В то же время, в последние годы Россия и Монголия соответственно корректируют торговые и экономические политики и значительно повышают требования к охране среды, экологии и т.д. Новые требования внес лик реализации экономического и торгового сотрудничества.

\section{4. Политические меры по углублению сотрудничества и обмена}

Решение указанных проблем должны продолжать совершенствовать соответствующую политику, возвышать всеобъемлющие возможности предприятия и порта, чтобы 
ускорять развитие внешней торговли в режиме смены. Между тем, для изменения торговли и охранены окружающей среды России и Монголии, необходимо исследовать активно и своевременно реагировать, а также руководство предприятия с иностранными инвестициями создать хорошее чувство конкуренция, стратегическое понимание бизнеса и социальной ответственности.

С точки зрения политики возникают конкретные политические меры. Например, в октябре 2011 года, Правительство АРВМ и Таможенное управление КНР подписали сотруднический меморандум, чтобы повышал уровень открытия внутренней Монголии. В соответствии с меморандумом, стороны будут работать вместе, чтобы способствовать развитию конкурентоспособных производств во Внутренней Монголии и строительством крупных проектов, повышать уровень строительства порта и открытия Внутренней Монголии, укреплять строительство во Внутренней Монголии оформление обычаи порта, продвинуть строительство специального таможенного контроли и строительство таможенных и контрольных зон АРВМ, содействовать торговому развитию внутренней границы Монголии, поддерживать нормальный порядок торговли импортом и экспортом, усиливать таможенную статистическую услугу, и совместно способствовать гармоничному развитию между таможней и местными органами управления. В то же время, Внутренняя Монголия подчеркнула в "12-й пятилетке", что заполнена открытость "недостатки" во время высокого уровня открытия, принять более активную и открытую политику, по-прежнему открывать новые области и пространства, содействовать открытый уровень, здание взаимовыгодных и победа победа характер всестороннего открытия, чтобы открыть и поощрять реформы, содействие развитию и поощрению инноваций 26 июня 2011, «введение Государственного совета по дальнейшему развитию нескольких видов Внутренней Монголии, звука и быстрого экономического развития» также предложил поддержать расширение внешнеэкономического и торгового сотрудничества во Внутренней Монголии, построить открытую платформу для сотрудничества. Для того, чтобы поощрять иностранные инвестиции в западные области, соответствующие ведомства Госсовета разработала ряд льготных мер.

Вышеуказанные меры политики, постепенное внедрение на месте, степень открытости во Внутренней Монголии будет масштабироваться на новую высоту в «12-й пятилетке" период будет иметь большее экономическое и торговое сотрудничество России с Монголией 